Review Article

UDC: $615.89(497.11+497.16)$; 616.31(091)(497.11+497.16)

ID: 202542604

\title{
Dragan Ilić
}

Assistant, Endodontics clinic

Faculty of Dental Medicine, University in Belgrade

Dr. Subotića 8, 11000 Belgrade, Serbia

dragan.ilic@stomf.bg.ac.rs

\section{ETHNODENTISTRY RESEARCH IN SERBIA AND MONTENEGRO} Abstract: Ethnodentistry (E), the branch of ethnomedicine, might be defined as
the scientific discipline which deals with collection and study on the folk customs in the scope of the knowledge on the causes and treating of the oral diseases, teeth and gums and orofacial diseases and anomaly. $\mathrm{E}$ records the survived empiric dentist's experiences, archaic terms and witchcraft elements and influence of magic elements to the oral hygiene. The first $\mathrm{E}$ research in Serbia were ran by Vera Gavrilović (1972), the professor-lecturer on the history of dentistry. There were no approved method for this pioneer research thus preliminary study resulted in many mistakes which pointed out to the construction of the adequate questionnaire valid for ethnodentistry research. Because of that and due to the political situation in the former Yugoslavia and later events (1991-2001), the polling was continued from 2002 to 2008. The aim of this research was to record the present folk dentistry knowledge (health culture) in 31 representative areas of Serbia and six of Montenegro (by the help of trained inquirers) concerning the data about treatment of oral and orofacial tissues (teeth, gums), dentist's standing as well as magic and religious elements involved in. The data were collected through the authors and students of Faculty of Stomatology in Belgrade using modification of original method 
on the sample of rural regions on the old person who were non-professional or "professional" folk dentists and herbalists by the additional help of local physicians and dentists. Operation on 1125 survey sheets classified into five groups revealed the most data about toothache (61) and the least (7) of magic recipes. The most valuable obtained data considered to be about plants whose active ingredients has not been yet used in dental pharmaceutical industry. The valuable suggestions might be directed to the contemporary applied pharmacology and those herbs that are growing on the still unpoluted isolated spots. Collected data might be of use for some social sciences (ethnology, linguistics, history etc.) Analysis of data pointed out to the very few wrong methods of treatment in traditional dentistry whereas majority of them noted as beneficial ones what depicted the health culture level of every single investigated region.

Keywords: ethnomedicine, folk medicine, phytotherapy

Non MeSH: ethnodentistry, ethnopharmacy, ethnobotanic, traditional dentistry, folk dentistry

Ključne reči: etnomedicina, narodna medicina, fitoterapija

$\mathrm{Ne} \mathrm{MeSH}$ : etnostomatologija, etnofarmacija, etnobotanika, tradicionalna zubna medicina, narodna zubna medicina

\section{Background}

Ethnodentistry (E), the branch of ethnomedicine, deals with collection and study of the folk customs about causes and treatment of oral and orofacial regions. [1] This medicine branch also notes survived empirical dentist skills, wealth and diversity of its terminology, influence of magic elements on the oral hygiene and treatment of orofacial region, particularly in part of people who was in close contact to the natural surroundings. Synonyms for $\mathrm{E}$ that could be found in contemporary literature such as folk dentistry, folk dental medicine, traditional dental medicine and traditional dentistry denote the same meaning. E besides ehnomedicine, ethnopharmacy and ethnoveterinary medicine present the branches of folk health culture. E is to be considered as interdisciplinary and composite field of science hence the data obtained from investigation should be assumed much wider, i.e. systematically through the prism of archaeology, history, general medicine, pharmacy, sociology and culturo- 
logy of the specific region. [2]

$\mathrm{E}$ investigations on the based on the clinical and laboratory tests on the scope of phototherapy had done all over the world mostly collecting the folk prescriptions in the large and middle-developed but densely populated countries (China, Brazil and India). The reason for doing so is still high participation of dental folk medicine in everday's life there, still cheap and what is the most important, reachable and at high level of dentistry knowledge. [2-8] Those countries' studies encourage the scientists to investigate the hidden recipes and active substances in medicinal herbs, useful for modern man exposed to stresses and suffering from the incurable diseases throughout the life.

The E studies in Balkan countries gave encouraging results (Macedonia, Bulgaria, Romania) where people used to apply knowledge and experience of folk dentistry like in Serbia due to the lack of educated doctors of dentistry. $[9,10]$

Traditional dental medicine has been developing through the centuries in the Serbia and Montenengo (SM), where the first manuscripts had originated in medieval period (Hilandar medical codex, Chodos collection etc). Interesting material for E research is still unprepared and insufficiently analysed (translated into Serbian) beginning with rare medieval Serbian medical manuscripts (Hilandar monasteries) that were concerned to the empirical, traditional and magic ways of treatment on the stomatological diseases and pathological descriptions as well. In that way, compound interventions have been applied only upon independency in $19^{\text {th }}$ century when population advanced culturally and many educated doctors of dentistry schooled abroad began to arrive in Serbia.

In previous centuries folk dentistry played important role concerning many wars, wounds, diseases and injuries left behind. In addition, Vuk Karadzic in his "Serbian glossary" mentioned around 130 medicinal plants. At the end of $19^{\text {th }}$ century the famous Serbian physician Vladan Đorđević wrote a book "Folk medicine" then followed the others such as Vasa Pelagić who wrote about prevention and treatment of oral and tooth disease, cited medicinal herbs and other methods. [11] This inheritage was of great importance during and after The First and Second World War.

Even after the Second World War, when public health was free of charge, medicinal plants were still popular for the common person. [8] Then systematically research began on the medicinal herbs conducting by J. Tucakov, French $\mathrm{PhD}$ scholar in 
pharmacognosy in the scope of Institute for pharmacognosy at the Faculty of Pharmacy in the late 1940's in Belgrade. As the first Serbian educated scientist in that field, he wrote "Treatment by herbs" of many reprints where lot of dentistry plants were mentioned.

As to our knowledge, there were no data from accessible sources of similar E. research had operated up to 1972 in Serbia and other Yugoslav republics. Then J. Tucakov gathered several enthusiasts in order to begin systematically research of the folk tradition on medicine, dentistry, veterinary medicine and pharmacy emphasized on critical and studiously observation of collected data. Four years later on (1976), they published the results of the first E. study "Folk health culture in the Socialist Republic of Serbia”. [12]

In the last century, up to 1970's, in the field of E. doctors of dentistry in the country also did not use organized and systematically research that were only operated by ethnologists who did it only casually. Yet in 1972. V. Gavrilovic, Belgrade Faculty of Stomatology (BFS) professor, began to work on pioneer E. study continuously up to 1991. Concerning the methodology, preliminary study was designed to find real good way of data collection. The final years students of BFS were included into research from 1976 and on through the summer terrain practice. Some of them collected the data using E. inquiry upon return to their domicile regions. All activities were conducted and supervised by VG within the BFS curriculum on "History of dentistry" including new trained associates members (lecturer's stuff). The pioneer mistakes that were dismissed in early 1980's when cleared questionnaire method began to give high quality results. Unfortunately, due to the socio-political situation in Serbia (1991-2001) E. research was stagnant but continued not until 2003, when some results about recipes for teeth and oral disease collected from SM had been reported. [13]

There is need to record the ancestor's dental medicine tradition as much as possible credible due to the strong and modern influence of the West, East and Mediterranean regions which threatens to erase that ample canon of folk dentistry. Here is J.Tucakov to say : "...it would be the great responsibility in front of history not to collect so precious folk medicine treasure created through the sufferings, pains and tears..." [12]

Concerning before mentioned, the close aims of this E. study were: 
- collecting of folk tradition knowledge about causes and symptoms of mouth and tooth diseases (dental care, oral hygiene, and correlation to the general health condition)

- studying on specific folk dental practice (professional traditional dentists, their curing doctrine and instruments, dentistry trade teaching, level of dental health culture, sorcerers and witch-doctors, patients' attitude toward folk dentists and contemporary dentistry)

- analysis of folk dentist terminology and knowledge on curing of dental diseases (jaw, gums and facial tissues as well as remedies preparation)

- magic and religious influence to the folk dentistry

\section{Material and method}

This research was conducted on the subject that means small groups of domicile population to whom traditional dentistry was not official profession, several folk herbalist (healer), folk dentists as well as old persons from cities and distant villages and settlements who dealt with folk dentistry deep in the past. Collected data from all of them were recorded "from memory", i.e. through the family background unfortunately without written papers arising from their own practice and lessons from “teachers". Data of some Serbian regions gave doctors of dentistry and GP's who secondarily gathered them from local old patients, folk-dentists and herbalists. This collecting method was proposed to be enough authentic for all regions in the country.

Preliminary study pointed out to the most appropriate data collecting way as immediate terrain method, whether it was individual or team. That method assumed direct data obtaining from all of those poled (subjects) through previously designed questionnaire. The research was running by the help of the trained pollsters: doctors of dentistry and students of BFS (final academic years). The polsters were warned about language during the pool where inquiry answers should be respect in the sense of exact noting in local dialect. Doing so, the original idioms could be regularly and linguistically interpret and explain. 
The data were obtained from 31 representative places around Serbia." The neighbouring regions of Serbia were also investigated by the same methodology where Serbs are prevailing or minority population by the help of BSF students originated from those places in order to make comparative analysis."

The research is still in progress in the areas of East Serbia and Banat to cover the territory of whole country. The study was done by the questionnaire consisted of the next summarized content written in plain folk language:

I. Recipes about oral, teeth and gums hygiene and are, teeth bleaching, tooth eruption and replacement as well as folk terminology concerning aforementioned

II. Recipes about mouth sore (thrush, cold sore, aphtha, herpes) diseases of lips, tongue and skin around mouth and folk expression about them

III. Recipes for tooth, gums and jaws treatment as well as folk terms about them

IV. The profession of folk dentist, training and their instruments

V. Magical (sorcery) rituals for tooth eruption, care of sound and treatment of rotten teeth.

The filled-in lists of questionnaire were classified by places (Tab.1) and statistically operated (Tab. 2).

* Vicinity of Sombor, Subotica, Novi Sad, Vršac, Bela Crkva, Eastern Srem, Pančevo, Požarevac, Šabac, Bogatić, Loznica, Obrenovac, villages around Belgrade, Bukulja and Venčac, Smederevska Palanka, Ćuprija, Čačak, Kraljevo, Kruševac, Niš, Pirot, Vranje, Kuršumlija, Prijepolje, Priboj and settlements on the mountains Fruška gora Rudnik, Divčibare, Tara, Zlatibor and Kopaonik.

* (Mediterranean and landlocked areas of Montenegro - Pljevlja, Podgorica, Bar, Kotor, Herceg-Novi, Nikšić, Bosnia/Republika Srpska - Bjeljina, Brčko, Kozara, Banja Luka, Podrinje and FYROM - Macedonian villages around Kumanovo and Skopje). The data of those regions are not prepared in this paper. 


\section{Results and results discussion}

The results of collected and partially worked out data are stored at the Department for History on Dentistry (FSB) that was managed by Prof. VG and Prof. Danica Zagradjanin at present. Classified and prepared material consists of total 1024 enquiry sheets (535 from period of 1972-1975, 489 from 1976-1991 and 2002-2008 period). The 41 data were obtained averagely by inquiry form that was 41984 informations for whole research.

The most enquiry lists were harvested in region of Šumadija where the highest number of research points were situated on especially during summer training course and voluntary masses 948 (83,4\%). Precisely, the most plentiful Šumadija localities were Kruševac 650 (63.4\%) and Ćuprija 297 (20.5\%).

The majority of interesting folk terminology data ("folk dental idioms") has still not worked out that would be classified as peculiar methodology unit of this research. The most answers from group I) are more or less similar prescriptions where 27 were noted (20.7\% of total research data). These recipes and those from group 2) and 3) could be summarized as: teas (decocts, infusions, macerates), extracts, herbal mixture with or without combination of edible fruits, teas combined of mineral ingredients and/or woody parts of plants, herbal mixtures with addition of pure chemicals (alcohol, methylated spirit) or Mediterranean or subtropic fruits (lemon, lavender, rosemary, clove, coffee grains) and some animal products (milk, cattle dung).

The ample source of stomatitis presents group II (26 recipes $-20.0 \%$ out of all data). Those were healing recipes of herbal mixtures and dietetic dishes. They are required to be the longer the better in contact to oral mucosa to expose salutary remedy effect. Very many idioms were recorded for variants of mouth sore conditions.

Based on the gathered data the most voluminous was group III (61 recipes $-46.9 \%$ out of all). That goes without saying if considering the great significance of dental pain for common peasant who is away even from provincial city and occupied by everyday's farmer chores having no time for qualified dentist visit.

Nine folk dental therapists (men) were enquired and described in the group IV (6.9\% out of all data). They were classified into four character types: 1) dental trade that is well kept secret learned from his ancestor handing on to succeeding genera- 
tion within the family (four subjects). They are believed that trade secret discovering out of the family brings to the loss of curing power; 2) dental trade learned from the "teacher" handing down to others (one answer); 3) like type 2) but keeps healing secret only for himself (three enquired persons), 4) dental skilfulness learned as self-taught where "secret of treatment" confides only to his close relatives (one inquired).

Some of them learned dental treatment interventions during war or military service especially extractions in position of doctor's assistant (apprentice). In peacetime, at homeland, they used their own instruments (forceps) made of iron or combined with wooden handle or equipment brought from military ambulance. There were "operators" who charged for the services by reasonable prices, some used compensation payment while others treat free of charge.

Group V contains only seven different "recipes of magic power" (5.5\% out of all). Minority of those answers point out to the high rate of failure by that way of treatment among the people who are more and more enlightened even in isolated spots. They give up more and more magic remedies accepting new therapy methods, but still preserve the custom of folk traditional substantial prescriptions (I, II and III groups' recipes) empirically approved as beneficial ones.

The authors of this study put the great effort into interpretation of medicinal herbs names and their synonyms as well as for classification on the similar, slightly varied prescriptions by composition and preparation mode that might be useful for botanical systematization of the phytotherapeutical species.

There were many folk jargons recorded about anatomical dental terms in all questionnaire groups as well as for diseases and medicinal plants that is interesting material for ethnolinguistical research.

\section{Discussion and conclusion}

In addition to, considering the study on the whole, the aim of this research was to explain the good and bad ways of archaic treatment and remedies through the centuries, to establish among that crowd what is doctrinary and medicinal right but what is unscientifically and wrong, harmful to one's health (toxic or inefficient).

The copious resulting material might be of confidential origin due to voluminous 
results and the direct method of data collecting, immediately obtained from the subjects such as "folk therapists" - healers and common people, often illiterate ones, even from isolated highland and lowland regions of Serbia.

The contemporary dental pharmacology and pharmacognosy should be benefited on the base of recorded recipes using herbs of still unpolluted areas around SM. The similar situation has already occurred in India upon completion of E. research (done in 2004) where 16 brand new herbal species discovered for treatment of dentalgia, aphtha, alveolar pyorrhoea, dental plaque and dental caries prevention. Those plants, up to that time, had not been recognized and classified in Indian ethnobotanical and phytotaxonomy literature! [6]

Italian ethnologists made the same recording several herbal recipes in Albanian immigrant population in Southern Italy unknown up to then. The added animal constituents were similar to the Serbian mixture-prescriptions. [5]

The plain population, mostly villagers and farmers were compelled to use cheap and "within reach" medicaments, which are amazingly similar to both Serbian and Dinka population (African mostly Christian Ethiopian-Sudanese tribe). Both of them used the ash mixture of burned cow dung for teeth cleaning by fingers. [14]

Some of recorded plants in our $\mathrm{E}$ study have the similar beneficial effect like sage. What a pity they are still not in use concerning the present of sage extracts in many dental products for oral care exposing, even five useful act such as antioxidant, antimicrobial, antifungicidal, adstringent, antiinflamatory and odorant. [15] Those plants are categorized into several pharmacological groups."

They expose useful effect in dental medicine through the next active principles: alkaloids, heterosides, saponins, ethereal oils of aromatic herbs, tannins, flavonoids, mucinous matters, phytocides, vitamins etc. Most of them demonstrate antioxidative, immunostimulating and anticancerous effects.

As to our knowledge, beside mineral substances the next inapplicable plant species and their derivatives in dental phytotherapy were noted in this E. study.* The benefit

* sialogogues, antisecretolytics, tonics, adstringents, styptics, antiseptics, sedatives, antineuralgics, anaesthetics, vulneraries, antibiotics and corrigenses

** broom, rosemary, chilli, coltsfoot flower, yellow iris, licorice, marigold, black grapes, cranberry, spinach, henbane, celandine, walnut leaf, onion, petal and oil of red rose, immortelle, garlic, 
of the study might be attributed to botany, botanic terminology, pharmacognosy and ethnopharmacy.

As far as wrong mode of traditional dental treatment, the most of sorcery and magic curing was noted in rural, very isolated places of Serbia. Nowadays, in those regions more and more experienced advantageous herbal prescriptions are in use even near contemporary dental offices. However, traditional dental recipes are often adjuvant and even competitive to modern ones because it is cheap and previously experienced as effective one.

Unfortunately, there are still no ways to collect the E. treasure from Kosovo and Metohia region due to political situation. That region would be of great interest due to existence of numerous isolated settlements with preserved customs in time interval too distant from contemporary life concerning ethnical and religious aspect of mixed population situated there.

The obtained data from the neighbouring countries (Republika Srpska, FYROM - Macedonia) have not yet operated in the scope of comparative analysis." They will be useful for study of immigrant change of life conditions and adaptation to new environments, similarity and differences of folk dental medicine knowledge in Serbia and Serbs who live abroad, neighbouring nations, ethnic and religious groups.

Usefulness of comparative analysis showed the ethnomedicinal studies in the regions of Eskimos, Papua island tribes, East Africans and Amazonian Brazil etc. [16,17] It is appropriately to quote the urgent and pressing words of Serbian pioneer in E, ethnomedicine and ethnopharmacy directed to generations to come. They pointed out even in 1976 of necessity to speed up the data analysis of E research in much detail because “...there is need to record the grandfather's medicine as soon as possible and truly because accelerative urban changes threatens to all of that heritage bring out of oblivion up to the end of $20^{\text {th }}$ century..." [12] The confirmation of aforementioned could find in academician Prof. dr K. Todorovic foreword of book "700 years in medicine in Serbs". There he wrote “...Serbs were going through the history through the different phases of military glory and power, advanced social root/leaf of blackberry, dandelion juice, yarrow, nettle, plantain, basil, chips of pine log, madder, common mallow, radish, grape hyacinth, rue, bilberry, blueweed, barberry, elder, calamus, hedge bindweed, orchid, pine marten resin, grain brandy, incense.

* Brčko, Bijeljina, Banjaluka, Trebinje, Kumanovo, Mediterranean and landlocked areas of Montenegro 
structure and cultural ascent, then fall and internal trouble, discord, and mutual rivalry and clashes, military ups and downs as well as long slavery, migrations and suffering where even bare life of nation was sometimes endangered..." [18]

Besides mainly biological aspect $\mathrm{E}$ in this study, socio-cultural focus might be of great importance for social science (ethnolinguistics, history etc.) analysed by professionals in those fields. Overall mentioned points to significance of carried out $\mathrm{E}$ research and data operations what altogether calls for further extension of our study encompassing the multidisciplinary approach and comparative analysis thoroughly.

\section{Table 1}

\section{Distribution of 1024 classified questionnaires by enquiry sites around Serbia}

\begin{tabular}{|l|r|l|r|l|r|l|r|}
\hline Sombor & 2 & Novi Sad & 8 & Vršac & 2 & East Srem & 2 \\
\hline Subotica & 2 & Fruška Gora & 1 & Bela Crkva & 7 & Beograd & 24 \\
\hline Pančevo & 1 & Šabac & 1 & Loznica & 1 & $\begin{array}{l}\text { Bukulja/ } \\
\text { Venčac }\end{array}$ & 2 \\
\hline Požarevac & 1 & Bogatić & 1 & Obrenovac & 2 & $\begin{array}{l}\text { Smeder. } \\
\text { Palanka }\end{array}$ & 1 \\
\hline Ćuprija & 297 & Divčibare & 2 & Zlatibor & 2 & Kraljevo & 4 \\
\hline Rudnik & 2 & Tara & 1 & Čačak & 1 & Kruševac & 649 \\
\hline Niš & 1 & Vranje & 1 & Kopaonik & 1 & Priboj & 2 \\
\hline Pirot & 2 & Kuršumlija & 1 & Prijepolje & 1 & TOTAL & 1024 \\
\hline
\end{tabular}

Table 2

Summarized table of different recipes and folk dentist's data

\begin{tabular}{|l|r|r|}
\hline Group & \multicolumn{2}{|c|}{ Data } \\
\hline I & 27 & $20,7 \%$ \\
\hline II & 26 & $20,0 \%$ \\
\hline III & 61 & $46,9 \%$ \\
\hline IV & 9 & $6,9 \%$ \\
\hline V & 7 & $5,5 \%$ \\
\hline TOTAL & 130 & $100 \%$ \\
\hline
\end{tabular}




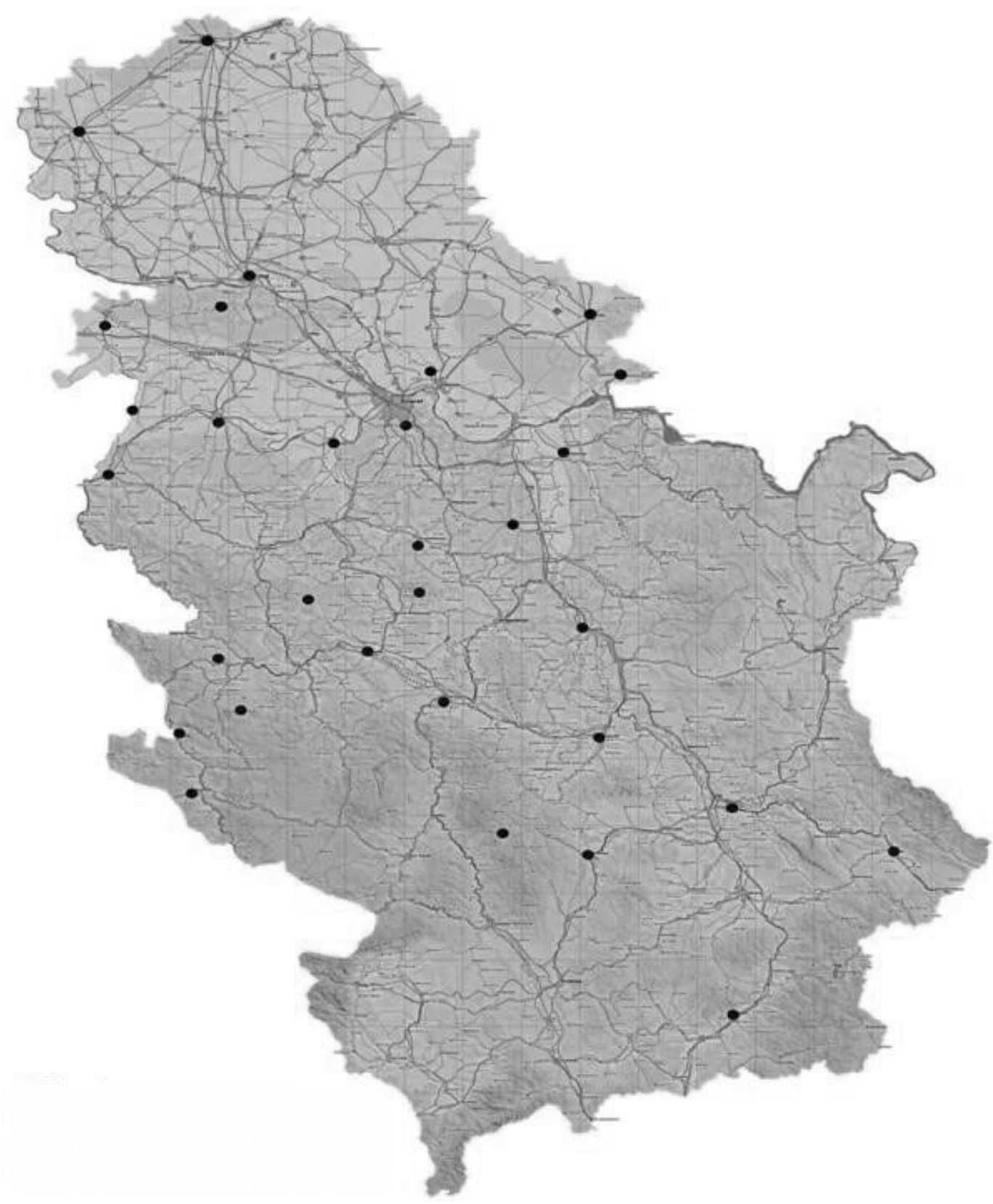

Figure 1. Map of inquiry spots in Serbia 


\section{References:}

1. Gavrilović V. Uvod u stomatologiju. Beograd: Medicinska knjiga; 1986. 180-99.

2. Živanović S. Medicinska antropologija. Beograd: Pešić i sinovi; 2005. 110-11.

3. Fukuchi K. et al. Inhibition of herpes simplex virus infection by tannins and related compounds. Antiviral Res 1989;11(5-6):285-98.

4. Sudworth R. The Use of Aloe Vera in Dentistry. 1997. Positive health. available: http://www.positivehealth. com//aloe-vera/the-use-of-aloe-vera-in-dentistry

5. Pieroni A, Quave C, Nebel S, Heinrich M. Ethnopharmacy of the ethnic Albanians (Arbëreshë) of northern Basilicata, Italy. Fitoterapia. 2002 Jun;73(3):217-41.

6. Patel VK, Venkatakrishna-Bhatt H Folklore therapeutic indigenous plants in periodontal disorders in India (review, experimental and clinical approach). Quintessenz. 1971;22(7):25.

7. Shen Jia et al. Hierarchy evaluation of pharmacological effects of Chinese herbal complex. 2007.

8. Herndon CN, Uiterloo M, Uremaru A., Plotkin MJ, Emanuels-Smith G, Jitan J. Disease concepts and treatment by tribal healers of an Amazonian forest culture. J Ethnobiol Ethnomed. 2009;5:27-49.

9. Bratoeva K, Bekyarova G, Kiselova Y, Ivanova D. Effect of Bulgarian herb extracts of polyphenols on metabolic disorders - induced by high-fructose diet. Trakia Journal of Sciences. 2010;8(Suppl. 2):56-60.

10. Nedelcheva AM., Dogan Y. and Guarrera PM. Plants traditionally used to make brooms in several European countries. Journ of Ethnobiology and Ethnomedicine. 2007;3:20.

11. Karadžić V. Sabrana dela, knjiga XVIII. Beograd: Prosveta; 1972.

12. Pelagić V. Narodni učitelj. Beograd: Narodna kultura; 1940.

13. Dragić M, Tucakov J, Divljanović D, Gavrilović V. Narodna zdravstvena kultura u SR Srbiji. Beograd: Naučno društvo za istoriju zdravstvene kulture 
Jugoslavije; 1976. 7-10, 43-98, 100-101, 116-118, 179-214.

14. Ilić VD, Jović P, Djukanović D. Ethnostomatological research in Serbia and Montenegro. Book of abstracts: 1st Balkan Congress on History of Medicine. Ohrid: FYRO Macedonia; 2003.

15. Willis MS, Harris LE, Hergenrader PJ. On traditional dental extractions case reports from Dinka and Nuer en route to restoration. Br Dent J. 2008;204:121-4.

16. www.share.com/question/are-the-health-benefits-sage

17. Živanović S. Bolesti drevnih ljudi. Beograd: Pešić i sinovi; 2000. 236-237.

18. Živanović S. Medicinska antropologija. Beograd: Pešić i sinovi; 2005. $133,135,155-6$.

19. Todorović K. 700 godina medicine u Srba. (monografija). Beograd: Srpska Akademija Nauke i Umetnosti; 1971.

\section{Rezime}

Etnostomatologija (E), grana etnomedicine, može se definisati kao disciplina koja se bavi prikupljanjem i izučavanjem običaja jednog naroda u vezi usne duplje i zuba, tj. uzrocima i lečenju oboljenja usta, zuba i orofacijalne regije. E takođe beleži bogatstvo narodne terminologije i uticaj magijskih i religijskih elemenata u narodnoj zubnoj medicini. Sveobuhvatna pionirska istraživanja iz ove oblasti započela je na našim prostorima prof. dr Vera Gavrilović sa Stomatološkog fakulteta u Beogradu sa grupom entuzijasta još davne 1972. Prikupljeni podaci s terena dobijeni prvobitnom metodologijom ukazali su na greške koje su neminovne u svakom pionirskom poduhvatu. Iz tih razloga kao i zbog istorijskih zbivanja u zemlji (1991-2001) istraživanja su intenzivnije nastavljena modifikovanom prvobitnom metodologijom (2002-2008). Ona su imala za cilj utvrđivanje stanja (nivoa) narodnih znanja o veštini lečenja zuba, desni i usne duplje uopšte, u savremenom okruženju u raznim reprezentativnim krajevima zemlje. Anketni list je sadržavao pitanja u vezi: narodnih znanja o nezi i lečenju desni i zuba, ustobolje, narodnih lekara-zubara i magijskih 
i religijskih elementima pri lečenja usta i zuba kao i narodnih zubarskih termina. Odgovori iz ankete su dobijeni od lokalnog stanovništva kojima narodno zubarstvo nije bila profesija a takodje i od narodnih lekara-vidara, travara, "narodnih zubara" kao i starijih lica iz sela i zabačenih zaselaka koji su se nekada profesionalno bavili narodnim zubarstvom ili sporadično ponegde to čine još i danas. Za pojedine oblasti anketirani su tamošnji doktori stomatologije ili medicine koji su podatke sekundarno dobijali od intervjuisanih pacijenata i nadri-lekara, zubara-berbera i travara. U istraživanju su učestvovali i obučeni anketari: stomatolozi i studenti završnih godina stomatologije sa Stomatološkog fakulteta u Beogradu. Podacima su obuhvaćeni skoro svi regioni Srbije (31) i Crne Gore (6 lokaliteta). Obradom 1125 anketa podaci su klasifikovani u pet grupa. Za zubobolju je zabeleženo najviše biljnih preskripcija (61) dok je magijskih "recepata" bilo najmanje (7). Kao najkorisniji podaci mogu se izdvojiti recepti u kojima su zastupljene biljke čiji se aktivni principi još uvek ne primenjuju u dentalnoj farmaceutskoj industriji. Značajne sugestije mogle bi se stoga uputiti savremenoj primenjenoj stomatološkoj farmakologiji (farmakognoziji i fitoterapiji) u smislu primene tih biljaka koje se na sreću još uvek mogu naći u industrijalizacijom nezagađenim zabačenim oblastima. Rezultati ovog istraživanja pružaju mogućnost za dalju analizu u pojedinim društvenim naukama (etnologija, lingvistika, itd.) Analizom podataka dobijeno je vrlo malo pogrešnih metoda lečenja tradicionalnim zubarstvom dok je većina bila ispravna što se pozitivno odražava na kulturni i zdravstveni nivo proučavanog regiona.

Submitted: 22. 6. 2013.

Reviewed: 7. 8. 2013.

Accepted: 17. 9. 2013. 